\title{
A perspective on regional and global strategies of multinational enterprises
}

\author{
Alan M Rugman ${ }^{1}$ \\ and Alain Verbeke ${ }^{2}$ \\ ${ }^{7}$ Kelley School of Business, Indiana University, \\ Bloomington, USA, ${ }^{2}$ Haskayne School of \\ Business, University of Calgary, Canada \\ Correspondence: \\ Professor AM Rugman, L Leslie Waters \\ Chair in International Business, Kelley \\ School of Business, Indiana University, 1309 \\ E. Tenth Street, Bloomington, IN 47401- \\ 1701, USA. \\ Tel: +18128555415 \\ Fax: +18128564971 \\ E-mail: rugman@indiana.edu
}

\begin{abstract}
Multinational enterprises (MNEs) are the key drivers of globalization, as they foster increased economic interdependence among national markets. The ultimate test to assess whether these MNEs are global themselves is their actual penetration level of markets across the globe, especially in the broad 'triad' markets of NAFTA, the European Union and Asia. Yet, data on the activities of the 500 largest MNEs reveal that very few are successful globally. For 320 of the 380 firms for which geographic sales data are available, an average of $80.3 \%$ of total sales are in their home region of the triad. This means that many of the world's largest firms are not global but regionally based, in terms of breadth and depth of market coverage. Globalization, in terms of a balanced geographic distribution of sales across the triad, thus reflects a special, and rather unusual, outcome of doing international business (IB). The regional concentration of sales has important implications for various strands of mainstream IB research, as well as for the broader managerial debate on the design of optimal strategies and governance structures for MNEs.

Journal of International Business Studies (2004) 35, 3-18. doi:10.1057/palgrave. jibs. 8400073
\end{abstract}

Keywords: firm-specific advantages; global strategy; localization; regional strategy; semi-globalization; triad; value chain

\section{Introduction}

Globalization, in the sense of increased economic interdependence among nations, is a poorly understood phenomenon. In this paper, we focus on the key actors in the globalization process, namely the firms that drive this process. A relatively small set of multinational enterprises (MNEs) accounts for most of the world's trade and investment. Indeed, the largest 500 MNEs account for over $90 \%$ of the world's stock of foreign direct investment (FDI) and they, themselves, conduct about half the world's trade (Rugman, 2000). Yet, this paper demonstrates that most of these firms are not 'global' companies, in the sense of having a broad and deep penetration of foreign markets across the world. Instead, most of them have the vast majority of their sales within their home leg of the 'triad', namely in North America, the European Union (EU) or Asia. This new view on 'globalization' is very different from the conventional, mainstream perspective. The latter perspective focuses primarily on macro-level growth patterns in trade and FDI, and compares these data with national GDP growth rates, but without ever analyzing the equivalent micro-level growth data for the MNEs responsible for the trade and FDI flows (United Nations, 2002).
Received: 21 April 2003

Revised: 14 October 2003

Accepted: 26 November 2003

Online publication date: 8 January 2004 


\section{The triad power concept}

American economic hegemony, characteristic of the post-World War II era, ended in the early 1970s. The closing of the gold window and the floating of the dollar in 1971 can be considered an early indicator of the new world order, with economic power more dispersed across the triad of North America, the EU and Asia. The evolution of the world stock of FDI is indicative of the relative decline in US economic power: in 1967 the United States still represented the majority (50.4\%) of the total stock of outward FDI; by 1990 this share had declined to only one-quarter (25.4\%) (Dunning, 2001). Van Den Bulcke (1995) provides an insightful account of the evolution toward a triadic world economy.

In 1985 Kenichi Ohmae, at that stage a leading McKinsey consultant in Japan, published his landmark study Triad Power, arguably one of the most insightful, international management books of the last two decades. The triad, in Ohmae's work, was a geographic space consisting of the United States, the EU and Japan. This geographic space, according to Ohmae, shares a number of commonalities: low macroeconomic growth; a similar technological infrastructure; the presence of large, both capitaland knowledge-intensive, firms in most industries; a relative homogenization of demand (with a convergence of required key product attributes); and protectionist pressures. The triad is home to most innovations in industry, and includes the three largest markets in the world for most new products.

A useful indicator of this 'core' triad's enduring importance is the concentration of the world's largest MNEs in the United States, the EU and Japan, as reported in Rugman (2000). In 2000, of the world's largest 500 MNEs, 430 had their corporate headquarters in these core triad regions. In 1996 it was 443, in 1991 it was 410, and back in 1981 it was 445 . The problem faced by many of these MNEs, according to Ohmae, is that they sell engineered commodities: that is, innovative and differentiated products, resulting from high investments in capital-intensive production processes and knowledge development. Unfortunately, these products rapidly lose their monopoly status. In spite of patents and brand names, technology often diffuses more rapidly to rivals than the required distribution capabilities can be built in foreign markets, thereby making it difficult to recoup innovation costs. The dilemma for any company that has developed a new 'superproduct' with large expected demand throughout the triad is thus as follows: setting up an extensive distribution capability for the product ex ante, throughout the triad, may entail high, irreversible, fixed costs, and therefore high risks, if the superproduct somehow does not deliver on its sales expectations. Conversely, if the superproduct is first marketed at home, rival companies in other legs of the triad are expected to rapidly create an equivalent product, capture their home triad region market, and dominate distribution in that market.

In this context, Ohmae introduces the concept of global impasse to describe the problems faced by even the largest companies to repeat their home triad base market share performance in the two other triad markets. Only a limited number of firms, such as Coca-Cola and IBM, have, according to Ohmae, succeeded in becoming a triad power. A triad power is defined as a company that has ' (1) equal penetration and exploitation capabilities, and (2) no blind spots, in each of the triad regions' (Ohmae, 1985: 165). In Ohmae's view the deep penetration into each triad market is critical to the recovery of innovation costs. The absence of blind spots is important in order to 'avoid surprises': that is, unexpected strategic moves by foreign rivals or home country competitors setting up alliances with foreign firms. A triad power is thus an MNE that has been successful in 'insiderization'. The importance of the absence of blind spots was also emphasized by Hamel and Prahalad (1985), who defined a global company as a firm with distribution systems in key foreign markets that permit cross-subsidization, international retaliation, and world-scale volume. These authors focused especially on the importance of strong, worldwide brand positions and distribution channels, and highlighted the limited value to large firms of mere cost advantages through offshore sourcing and rationalized manufacturing.

Given the global impasse challenge described above, Ohmae (1985: Chapter 12) suggests the use of consortia and joint ventures to capture the nonhome triad markets. In case the MNE wishes to become a triad power on its own, through wholly owned operations, Ohmae prescribes an 'Anchorage' perspective: that is, a corporate center that is mentally located in Anchorage (Alaska), equidistant from the economic and political power bases in the United States, the EU and Japan. This is in line with Perlmutter's (1969) prescription of developing a geocentric mentality in MNEs. In practice, such a firm should operate with regional head- 
quarters in each leg of the triad in order to capitalize on commonalities within each region, at a lower cost and with more market knowledge than if corporate headquarters performed those activities.

Finally, Ohmae (1985) contains one last important insight, namely that MNEs from each triad region should identify a fourth region, where it should be easy, relative to the rest of the world, to earn an important market share. This fourth region will depend on the industry and firm involved, but for Japan it would typically include Asian markets, for the United States its neighboring trading partners, and for Europe those countries with which much trade or trade potential exists.

However, Ohmae (1985) did not actually anticipate the extension of the core triad to the 'broad' triad of today. The broad triad consists of NAFTA, the expanded EU and Asia. In parallel with the introduction of the Canada US Free Trade Agreement in 1989, NAFTA in 1994 and its expansion to the Free Trade Area of the Americas by 2005, the EU will further expand to 25 countries in 2004 (and perhaps more in the future). In Asia, in November 2002, China agreed to a free trade agreement with the 10 members of the Association of South East Asian Nations (ASEAN), signaling a wide trade and investment agreement for Asia. In September 2003, India and the ASEAN members agreed to forge a free trade area by 2012, while Japan and ASEAN agreed to begin negotiations on far-reaching trade and investment liberalization by 2005 . Such institutional arrangements represent the agglomeration of attractive, proximate foreign markets (from a geographical, cultural, economic, and administrative perspective) into a 'broad' triad region. This will facilitate even deeper intra-regional market penetration. In contrast, little progress has been achieved in recent years in the realm of more global integration among nations through multilateral negotiations, especially at the level of the World Trade Organization (WTO). This situation is not expected to improve in the near future (for a discussion, see Rugman and Verbeke (2003)). At present, a majority of trade is intra-regional, and conducted in each part of the broad triad of NAFTA, the EU and Asia (Rugman, 2000).

The present paper tests whether the world's largest firms have been capable of implementing Kenichi Ohmae's visionary strategy and becoming (broad) triad powers during the two decades after his path-breaking book. Our work has three caveats. First, our paper presents data on the distribution of sales across the broad triad regions. This should be considered as a starting point for introducing systematically a regional component in international business (IB) research. Individual MNEs may be faced with specific environmental requirements/ opportunities, as well as internal company ones that suggest a different regional delineation, consistent with Ghemawat's (2001) framework on the 'distance' between countries. In a similar vein, the subnational level (i.e. regions within a single country) may also be important in the IB context, both for manufacturing location decisions and for the targeting of specific subnational areas for sales and distribution. Second, a balanced distribution of sales across the triad, although likely beneficial to an MNE's sustained performance, is not necessarily critical to all MNEs. For example, firms may attempt to establish a dominant position in their home market, and may have little interest in pursuing a balanced, triad-based distribution of sales. Third, different activities in the value chain may be associated with varying levels of globalization. In this paper we focus primarily on sales, simply because these constitute the ultimate reflection of market success, but we also discuss the issue of downstream $v s$ upstream globalization.

\section{Empirical evidence of triad power}

The 500 largest companies in the world accounted for over \$14 trillion of total sales (revenues) in fiscal year 2001. The average revenues for a firm in the top 500 were $\$ 28$ billion, ranging from Wal-Mart at $\$ 220$ billion to Takenaka at $\$ 10$ billion. In this study of the intra-regional sales of these 500 firms, a total of 380 were included with available geographic segment data. These 380 firms account for $79.2 \%$ of the total revenues of all the 500 firms. The average sales volume of a firm in the set of 380 is $\$ 29.2$ billion. Across these 380 large firms the average intra-regional sales represent $71.9 \%$.

A relative sales dominance in a specific regional market, rather than a very wide and evenly distributed spread of sales, reflects five underlying issues critical to the MNE's functioning. First, if most MNEs' sales are unevenly distributed across the globe, and usually concentrated in just one geographic market, this means that the firms' products are not really equally accessible and/or attractive to consumers all around the world, in spite of many MNEs attempting to adapt their products to local demand.

Second, the lack of global market success, although based on aggregate company-level data, 
could be interpreted as a reflection of the limits to the non-location-bound nature of the MNEs' knowledge base - that is, their firm-specific advantages (FSAs). Firms may have sophisticated and proprietary technological knowledge, brand names, etc., but there may be severe limits to the joint international transferability of this knowledge, and its acceptance by customers across regions. These limits may exist irrespective of whether the knowledge is embodied in final products and then exported, transferred as an intermediate product through licensing, or utilized in foreign affiliates through FDI. It should be recognized that some examples exist of rapid cross-border integration of sales, as exemplified by the success of Airbus aircraft in the United States, Japanese cars in Europe, and a variety of American consumer goods in Japan and China, but the magnitude of this trend, as compared with overall sales volumes, remains small across the 500 largest companies.

Third, the observed lack of market performance across regions may also point to a relative inability to access and deploy the required location-bound FSAs, which would lead to benefits of regional and national responsiveness.

Fourth, if the MNE's market position is very different in the various regions of the world this indicates the need for very different competitive strategies: a leadership role in one market may require different patterns of decisions and actions than the role of a (perhaps ambitious) junior player in another market. These differential roles should then be reflected in the deployment of specific combinations of non-location-bound and locationbound FSAs in each region. Unfortunately, in spite of much 'think global, act local' rhetoric in both the academic and popular business press, there appears to be little empirical evidence that this approach has permitted host region market penetration levels similar to those obtained in the home region.

Fifth, the four elements above have important implications for MNE governance. It might be incorrect to attribute the present relative lack of overseas market success of many firms to an inappropriate governance structure. The presence of multiple environmental circumstances may also be critical here (powerful foreign rivals in other triad regions; government shelter of domestic industries; buyer preferences for local products; cultural and administrative differences as compared to the home region; etc.). However, the need for regional strategies does suggest the parallel intro- duction of a regional component in the MNEs' governance structure to deal appropriately with the distinctive characteristics of each leg of the triad, and with the regions outside it, much in line with Ohmae's (1985) prescriptions. This perspective is developed further in the later sections of the paper.

This need for distinct regional strategies should be viewed as a complement to the well-known normative models that advocate simple globalization strategies as a set of purposive decisions and actions instrumental to a broad and deep penetration of foreign markets (Govindarajan and Gupta, 2001; Jeannet, 2000; Yip, 2002). Regionalization should be viewed as an expression of semi-globalization (Ghemawat, 2003). Semi-globalization implies that we observe neither extreme geographical fragmentation of the world in national markets nor complete integration. Incomplete integration means that location specificity, in this case regional specificity, matters. Only in the context of incomplete integration is there scope for international MNE strategy that is conceptually distinct from conventional domestic strategy.

\section{Empirical evidence and meaning of regional strategies}

The majority of the world's largest 500 companies (the Fortune 500) are MNEs: that is, they produce and/or distribute products and/or services across national borders. Yet, very few MNEs have the ability to sell standardized products and services around the world, a type of globalization originally advocated by Levitt (1983). In the mainstream IB literature it is now widely recognized that benefits of integration resulting from global-scale economies can be reaped only if accompanied by strategies of national responsiveness, guided by both external pressures for local adaptation and internal pressures for requisite variation. What is unfortunately often neglected is that, irrespective of MNEs' efforts to augment their alleged nonlocation-bound FSAs with a location-bound component, no balanced geographical dispersion of sales is achieved in most cases.

For 365 of the 380 firms included in our study, data were available that permitted a further decomposition of their foreign sales. It should be noted that many of the remaining 135 Fortune 500 companies are actually operating solely in their home region, with no sales elsewhere, and for others there are insufficient data. Of the 365 with data, only nine MNEs are unambiguously 'global', with at least $20 \%$ of their sales in all three regions of 
the triad, but less than $50 \%$ in any one region. This picture of regionalization, rather than globalization, is shown in Table 1.

The definitions adopted in Table 1 are as follows:

(1) Home region oriented: In all, 320 firms have at least $50 \%$ of their sales in their home region of the triad. The threshold of $50 \%$ was chosen as we assume that a region representing more than $50 \%$ of total sales will systematically both shape and constrain most important decisions and actions taken by the MNE. It also implies a concentration of the MNE's downstream FSAs in that region, as explained in the next section.

(2) Bi-regional: In all, 25 MNEs are bi-regional, defined as firms with at least $20 \%$ of their sales in each of two regions, but less than $50 \%$ in any one region. This set includes 25 firms with sales ranging between 20 and 50\% in the home region and $20 \%$ or over in a second region. The threshold of $20 \%$ was chosen because we assume that having two regional markets, each representing at least one fifth of a large firm's sales, reflects impressive market success resulting from extensive downstream FSAs in those two markets.

(3) Host region oriented: In all, 11 firms have more than $50 \%$ of their sales in a triad market other than their home region.

(4) Global: Only nine of the MNEs included are global, defined as having sales of $20 \%$ or more in each of the three parts of the triad, but less than $50 \%$ in any one region of the triad. The

Table 1 Classification of the top 500 MNEs

\begin{tabular}{|c|c|c|c|c|}
\hline Type of MNE & $\begin{array}{l}\text { No. of } \\
\text { MNEs }\end{array}$ & $\begin{array}{c}\text { Percentage } \\
\text { of } 500\end{array}$ & $\begin{array}{c}\text { Percentage } \\
\text { of } 380\end{array}$ & $\begin{array}{c}\text { Percentage } \\
\text { intra-regiona } \\
\text { sales }\end{array}$ \\
\hline Global & 9 & 1.8 & 2.4 & 38.3 \\
\hline Bi-regional & 25 & 5.0 & 6.6 & 42.0 \\
\hline $\begin{array}{l}\text { Host region } \\
\text { oriented }\end{array}$ & 11 & 2.2 & 2.9 & 30.9 \\
\hline $\begin{array}{l}\text { Home region } \\
\text { oriented ( } 1)\end{array}$ & 320 & 64.0 & 84.2 & 80.3 \\
\hline Insufficient data & 15 & 3.0 & 3.9 & 40.9 \\
\hline No data & 120 & 24.0 & & NA \\
\hline Total & 500 & 100.0 & 100.0 & 71.9 \\
\hline
\end{tabular}

Data are for 2001.

Source: Braintrust Research Group, The Regional Nature of Global Multinational Activity, 2003 (www.braintrustresearch.com).

$\mathrm{NA}=$ not available
$20 \%$ figure is less than the one-third required for an equal triad distribution, and so is biased downwards in favor of finding global MNEs. Conceptually, it implies the successful deployment of downstream FSAs in three distinct markets. The North American and European region of the broad triad are of approximate equal size, as measured by GDP. Asia is smaller than either as measured by GDP, but is nearly equal when taking into account purchasing power parity (PPP). Weighing the three legs of the broad triad by GDP, and even correcting for PPP, will not generate a larger number of global firms.

Within each of the groups above, the home triad region sales weighted averages are as follows:

(1) home region oriented (320 firms): $80.3 \%$;

(2) bi-regional (25 firms): $42 \%$;

(3) host region oriented (11 firms): $30.9 \%$; and

(4) global (nine firms): $38.3 \%$

The above data also confirm the study of the 49 retail MNEs in the 500, by Rugman and Girod (2003). In that study, only one retail MNE was found to be global, namely LVMH (Moët Hennessy Louis Vuitton SA). While it could be argued that there is much more to globalization than sales dispersion - for example, foreign assets and foreign employment have sometimes been used together with foreign sales to compose a transnationality index - it should be recognized that only sales dispersion constitutes a true performance measure at the output level. In this context, Rugman and Brain (2003) report an analysis of the regional sales of the world's 20 most transnational firms as defined by the United Nations' World Investment Report 2002. Of these 20 firms with the highest transnationality index, only one was global, namely Philips. Another five were bi-regional. Two were host region oriented. Of the 20 most transnational firms, 12 were home region oriented.

Given the above classification of MNEs, we should note five limitations of the data for purposes of strategy prescription. First, most large MNEs consist of several strategic business units (SBUs); the geographical sales distribution may vary for each SBU, even within a single MNE. Second, although the percentage thresholds adopted $(50 \% ; 20 \%)$ are to permit a coherent analysis across the sample of companies, the actual sales percentages perceived by management as a reflection of successful 
presence in host triad regions may differ from firm to firm. Owing to data limitations it may be difficult to attribute particular sales to a specific region. For example, Asian tourists may purchase a substantial part of the total sales of a European luxury goods manufacturer duty-free in the United States, and those sales would be registered as US based. Similarly, industrial goods may be sold to global accounts located in another leg of the triad, but the sales might still be registered in the home region. Third, the implications of particular sales percentages for differential corporate strategy and structure across the triad may also be firm specific. Fourth, large home region sales percentages do not imply the absence of vulnerability to outsiders. The case of the US automobile industry suggests that even large market shares in the home region may be eroded over time by dynamic rivals from other legs of the triad. Fifth, the minimum market share (and therefore firm-level sales volume) required in host regions to permit effective rivalry, and even retaliation against domestic incumbents, is largely industry specific, and not captured by the data.

The nine triad-based global MNEs are identified in Table 2. Most of these MNEs are in the computer, telecom, and hi-tech sectors. These global firms are spread across the triad, with three in each region of North America, Europe, and Asia-Pacific.

The bi-regional MNEs are listed in Table 3. This table includes MNEs such as Unilever and McDonald's, which are nearly global (in both cases they have under $20 \%$ of their sales in Asia). These bi-regional MNEs may be well positioned to extend their market reach further, across all three triad markets. Most bi-regionals are European or Asian firms with successful access to the US market. There are only six North American bi-regionals.

The 11 host region MNEs are reported in Table 4 . These include DaimlerChrysler as one of eight MNEs with head offices in Europe, but with more than half of their sales in North America. There are also two Asian businesses, Honda and the Australian-based News Corporation, which have most of their sales in North America. Only one US MNE, Manpower, has more sales in Europe than in its home market. Most of these MNEs have been attracted by the size of the US economy. Their geographical expansion strategies have been driven by market access considerations and, in several cases, as with DaimlerChrysler, have been largely implemented through mergers and acquisitions, reflecting to some extent the inability to

Table 2 Global MNEs

\begin{tabular}{|c|c|c|c|c|c|c|c|c|c|}
\hline & $\begin{array}{l}500 \\
\text { rank }\end{array}$ & Company & Region & $\begin{array}{c}\text { Revenues } \\
\text { (US\$bn) }\end{array}$ & $\begin{array}{c}F / T \\
\text { sales }\end{array}$ & $\begin{array}{c}\text { Percentage } \\
\text { intra-regional }\end{array}$ & $\begin{array}{c}\text { North America } \\
\text { percentage } \\
\text { of total sales }\end{array}$ & $\begin{array}{c}\text { Europe } \\
\text { percentage } \\
\text { of total sales }\end{array}$ & $\begin{array}{c}\text { Asia-Pacific } \\
\text { percentage } \\
\text { of total sales }\end{array}$ \\
\hline 1 & 19 & $\begin{array}{l}\text { Intl. Business } \\
\text { Machines }\end{array}$ & North America & 85.9 & 64.8 & 43.5 & $43.5^{\mathrm{a}}$ & $28.0^{\mathrm{b}}$ & 20.0 \\
\hline 2 & 37 & Sony & Asia-Pacific & 60.6 & 67.2 & 32.8 & $29.8^{c}$ & 20.2 & $32.8^{d}$ \\
\hline 3 & 143 & $\begin{array}{l}\text { Royal Philips } \\
\text { Electronics }\end{array}$ & Europe & 29.0 & NA & 43.0 & $28.7^{\mathrm{e}}$ & 43.0 & 21.5 \\
\hline 4 & 147 & Nokia & Europe & 27.9 & 98.5 & 49.0 & $25.0^{\mathrm{a}}$ & 49.0 & 26.0 \\
\hline 5 & 162 & Intel & North America & 26.5 & 64.6 & 35.4 & $35.4^{c}$ & 24.5 & 40.2 \\
\hline 6 & 190 & Canon & Asia-Pacific & 23.9 & 71.5 & 28.5 & $33.8^{\mathrm{a}}$ & 20.8 & $28.5^{\mathrm{d}}$ \\
\hline 7 & 239 & Coca-Cola & North America & 20.1 & NA & 38.4 & 38.4 & $22.4^{b}$ & 24.9 \\
\hline 8 & 388 & $\begin{array}{l}\text { Flextronics } \\
\text { International }\end{array}$ & Asia-Pacific & 13.1 & NA & 22.4 & $46.3^{c}$ & 30.9 & 22.4 \\
\hline \multirow[t]{3}{*}{9} & 459 & LVMH & Europe & 11.0 & 83.4 & 36.0 & $26.0^{c}$ & 36.0 & 32.0 \\
\hline & & $\begin{array}{l}\text { Weighted } \\
\text { average }\end{array}$ & & 33.1 & & 38.3 & & & \\
\hline & & Total & & 298.0 & & & & & \\
\hline
\end{tabular}

Data are for 2001

Source: Braintrust Research Group, The Regional Nature of Global Multinational Activity, 2003 (www.braintrustresearch.com).

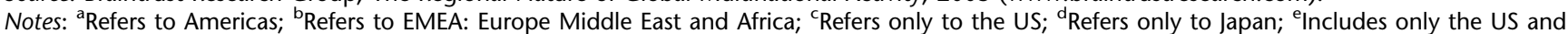
Canada.

$\mathrm{NA}=$ not available. 
Table 3 Bi-regional MNEs

\begin{tabular}{|c|c|c|c|c|c|c|c|c|c|}
\hline & $\begin{array}{l}500 \\
\text { rank }\end{array}$ & Company & Region & $\begin{array}{l}\text { Revenues } \\
\text { (US\$bn) }\end{array}$ & $\begin{array}{c}F / T \\
\text { sales }\end{array}$ & $\begin{array}{l}\text { Percentage } \\
\text { intra-regional }\end{array}$ & $\begin{array}{c}\text { North America } \\
\text { percentage } \\
\text { of total sales }\end{array}$ & $\begin{array}{c}\text { Europe } \\
\text { percentage } \\
\text { of total sales }\end{array}$ & $\begin{array}{l}\text { Asia-Pacific } \\
\text { percentage } \\
\text { of total sales }\end{array}$ \\
\hline 1 & 4 & $\mathrm{BP}$ & Europe & 174.2 & 80.4 & 36.3 & $48.1^{\mathrm{a}}$ & 36.3 & NA \\
\hline 2 & 10 & Toyota Motor & Asia-Pacific & 120.8 & 50.8 & 49.2 & 36.6 & 7.7 & $49.2^{b}$ \\
\hline 3 & 58 & Nissan Motor & Asia-Pacific & 49.6 & 50.3 & 49.7 & 34.6 & 11.0 & $49.7^{b}$ \\
\hline 4 & 68 & Unilever & Europe & 46.1 & NA & 38.7 & 26.6 & 38.7 & 15.4 \\
\hline 5 & 138 & Motorola & North America & 30.0 & 56.0 & 44.0 & $44.0^{\mathrm{a}}$ & 14.0 & 26.0 \\
\hline 6 & 140 & GlaxoSmithKline & Europe & 29.5 & 50.8 & 28.6 & $49.2^{\mathrm{a}}$ & 28.6 & NA \\
\hline 7 & 153 & EADS & Europe & 27.6 & NA & 44.9 & 33.7 & 44.9 & 10.2 \\
\hline 8 & 158 & Bayer & Europe & 27.1 & NA & 40.3 & 32.7 & 40.3 & 16.1 \\
\hline 9 & 210 & LM Ericsson & Europe & 22.4 & 97.0 & 46.0 & 13.2 & $46.0^{c}$ & 25.9 \\
\hline 10 & 228 & Alstom & Europe & 20.7 & 88.0 & 45.1 & 28.0 & 45.1 & 16.1 \\
\hline 11 & 230 & Aventis & Europe & 20.5 & 87.2 & 32.1 & $38.8^{d}$ & 32.1 & $6.4^{\mathrm{b}}$ \\
\hline 12 & 262 & Diageo & Europe & 18.6 & NA & 31.8 & 49.9 & 31.8 & 7.7 \\
\hline 13 & 268 & Sun Microsystems & North America & 18.3 & 52.6 & 47.4 & $47.4^{\mathrm{a}}$ & $30.2^{c}$ & 17.2 \\
\hline 14 & 285 & Bridgestone & Asia-Pacific & 17.6 & 61.2 & 38.8 & $43.0^{\mathrm{e}}$ & 10.1 & $38.8^{\mathrm{b}}$ \\
\hline 15 & 288 & Roche Group & Europe & 17.3 & 98.2 & 36.8 & 38.6 & 36.8 & 11.7 \\
\hline 16 & 316 & $3 \mathrm{M}$ & North America & 16.1 & 53.1 & 46.9 & $46.9^{\mathrm{a}}$ & 24.6 & 18.9 \\
\hline 17 & 317 & Skanska & Europe & 15.9 & 83.0 & 40.0 & 41.0 & 40.0 & NA \\
\hline 18 & 340 & McDonald's & North America & 14.9 & 62.4 & 40.4 & $40.4^{d}$ & 31.9 & 14.8 \\
\hline 19 & 342 & Michelin & Europe & 14.6 & NA & 47.0 & 40.0 & 47.0 & NA \\
\hline 20 & 383 & Eastman Kodak & North America & 13.2 & NA & 48.5 & $48.5^{\mathrm{a}}$ & $24.7^{c}$ & 17.2 \\
\hline 21 & 386 & Electrolux & Europe & 13.1 & NA & 47.0 & 39.0 & 47.0 & 9.0 \\
\hline 22 & 390 & BAE Systems & Europe & 13.0 & 82.7 & 38.1 & $32.3^{d}$ & 38.1 & 2.7 \\
\hline 23 & 408 & Alcan & North America & 12.6 & 95.4 & 41.1 & $41.1^{d}$ & 39.6 & 13.9 \\
\hline 24 & 415 & L'Oréal & Europe & 12.3 & NA & 48.5 & 32.4 & 48.5 & NA \\
\hline \multirow[t]{3}{*}{25} & 416 & Lafarge & Europe & 12.3 & NA & 40.0 & 32.0 & 40.0 & 8.0 \\
\hline & & Weighted average & & 31.1 & & 42.0 & & & \\
\hline & & Total & & 778.3 & & & & & \\
\hline
\end{tabular}

Data are for 2001.

Source: Braintrust Research Group, The Regional Nature of Global Multinational Activity, 2003 (www.braintrustresearch.com).

Notes: ${ }^{a}$ Refers only to the US; ${ }^{b}$ Refers only to Japan; ${ }^{c}$ Refers to EMEA: Europe Middle East and Africa; ${ }^{d}$ Includes only the US and Canada; ${ }^{\text {Refers to }}$ Americas.

$\mathrm{NA}=$ not available.

achieve a similar penetration through internal, organic growth.

Table 5 lists the 25 largest home region oriented MNEs. As noted above, there are 320 of these. They pursue essentially an intra-regional strategy.

A small set of firms are 'near miss' global MNEs, as they approximate the percentages required to be considered global. One subset includes ExxonMobil, Royal Dutch/Shell and Nestlé, which are probably global in terms of geographic spread of their sales, but cannot be so classified due to absent data. Several firms, such as Aventis, are bi-regional and probably would be classified as global if the missing data for Asia were available. Four other MNEs, namely McDonald's, Eastman Kodak, Anglo-American, and 3M, just miss the 'global firm' status. For example, McDonald's has only $14.8 \%$ of sales in
Asia, Eastman Kodak has only 17.2\%, Anglo American has $17.8 \%$, and $3 \mathrm{M}$ has $18.9 \%$.

\section{Some special cases}

The two MNEs conventionally regarded as 'global', indeed as primary agents of globalization, are CocaCola and McDonald's. Yet, only Coca-Cola is truly a global MNE. Ranking as 129th in the Fortune 500 list, it has over $20 \%$ of its sales across all three parts of the triad: $38.4 \%$ in North America, $22.4 \%$ in Europe, and $24.9 \%$ in Asia. Of Coca-Cola's sales in Asia, $74 \%$ are in Japan, but the company is attempting to increase its market in China. In contrast, McDonald's, ranked as 340th in the Fortune 500 list, is a bi-regional MNE. It has 36.6\% of its sales in North America, 37.1\% in Europe, but only $13.8 \%$ in Asia. 
Table 4 Host region-based MNEs

\begin{tabular}{|c|c|c|c|c|c|c|c|c|c|}
\hline & $\begin{array}{l}500 \\
\text { rank }\end{array}$ & Company & Region & $\begin{array}{l}\text { Revenues } \\
\text { (US\$bn) }\end{array}$ & $\begin{array}{l}F / T \\
\text { sales }\end{array}$ & $\begin{array}{c}\text { Percentage } \\
\text { intra-regional }\end{array}$ & $\begin{array}{c}\text { North America } \\
\text { percentage } \\
\text { of total sales }\end{array}$ & $\begin{array}{c}\text { Europe } \\
\text { percentage } \\
\text { of total sales }\end{array}$ & $\begin{array}{l}\text { Asia-Pacific } \\
\text { percentage } \\
\text { of total sales }\end{array}$ \\
\hline 1 & 7 & DaimlerChrysler & Europe & 136.9 & NA & 29.9 & 60.1 & 29.9 & NA \\
\hline 2 & 20 & ING Group & Europe & 83.0 & 77.3 & 35.1 & 51.4 & 35.1 & 3.4 \\
\hline 3 & 38 & Royal Ahold & Europe & 59.6 & 85.0 & 32.8 & 59.2 & 32.8 & 0.6 \\
\hline 4 & 41 & Honda Motor & Asia-Pacific & 58.9 & 73.1 & 26.9 & 53.9 & 8.1 & $26.9^{\mathrm{a}}$ \\
\hline 5 & 136 & $\begin{array}{l}\text { Santander Central } \\
\text { Hispano Group }\end{array}$ & Europe & 30.4 & 66.1 & 44.3 & $55.7^{\mathrm{b}}$ & 44.3 & NA \\
\hline 6 & 245 & Delhaize 'Le Lion' & Europe & 19.6 & 84.0 & 22.0 & 75.9 & 22.0 & 1.0 \\
\hline 7 & 301 & AstraZeneca & Europe & 16.5 & NA & 32.0 & $52.8^{c}$ & 32.0 & $5.2^{\mathrm{a}}$ \\
\hline 8 & 364 & News Corp. & Asia-Pacific & 13.8 & NA & 9.0 & $75.0^{c}$ & $16.0^{d}$ & 9.0 \\
\hline 9 & 476 & Sodexho Alliance & Europe & 10.6 & NA & 42.0 & 50.0 & 42.0 & NA \\
\hline 10 & 482 & Manpower & North America & 10.5 & 80.9 & 19.1 & $19.1^{c}$ & 68.6 & NA \\
\hline \multirow[t]{2}{*}{11} & 487 & Wolseley & Europe & 10.4 & 79.1 & 28.7 & 66.3 & 28.7 & NA \\
\hline & & Weighted average & & 40.9 & & 30.9 & & & \\
\hline
\end{tabular}

Data are for 2001.

Source: Braintrust Research Group, The Regional Nature of Global Multinational Activity, 2003 (www.braintrustresearch.com). Notes: ${ }^{a}$ Refers only to Japan; ${ }^{b}$ Refers to Americas; ${ }^{c}$ Refers only to the US; ${ }^{d}$ Refers only to the UK.

$\mathrm{NA}=$ not available.

Nike is another interesting case. It is not one of the largest 500 firms, as its sales are under $\$ 10$ billion. It sources $99 \%$ of its products offshore, primarily in China (38\%) and South East Asia (61\%), and much of its apparel (86\%) is produced outside the United States. Yet, Nike is a company with the majority of its sales in the Americas (58.2\%). Indeed, it has $52.1 \%$ of sales in its home market of the United States. Nike also competes in Europe with $29 \%$ of its sales there, but not much in Asia with only $12.9 \%$ of sales there.

In terms of employment, of the 22,000 Nike employees, over half are located in the United States (54.7\%). If we include other countries in the Americas, this number rises to $60.2 \%$. Europe, the Middle East and Africa account for another 24.9\%. Asia and the Pacific account for about $14.9 \%$ (or 3000 employees), but this region is also home to about 660,000 employees of independent contract companies that supply Nike products. These independent contractors are not owned by Nike, but are part of its supply network. Nike is only indirectly responsible for the working conditions of the employees working for these independent firms. Yet, owing to the adverse perceived impact on its brand image of 'sweatshop' conditions in these factories, Nike is now assuming some responsibility for the labor conditions in the factories of its independent suppliers.
The Nike case indicates the importance of understanding the precise FSAs of an MNE. Nike is not successful because it outsources most of its production in Asia. Instead, it outperforms other competitors because of its business model, in which its brand name is the dominant FSA. This brand name signifies high-quality, stylish, 'cool' sports shoes and sports apparel. All its competitors also outsource in South East Asia significant portions of production. This access to cheap labor represents a country factor condition, not an FSA by itself. In a similar vein, Wal-Mart outperforms other firms owing to its unique business model, not primarily by outsourcing to China. These firms' outsourcing strategies reflect internalization arbitrage - more specifically the ability to link attractive (but generally available), host country production factors, used at the upstream end of the value chain with upstream FSAs. However, only in the presence of downstream FSAs (especially branding) do such strategies lead to market success, and this is often restricted to the home triad region. The Nike and Wal-Mart cases illustrate the crucial importance of the sales data used in this paper to assess market success.

\section{Implications for emerging research themes}

In this section, some of the implications of the lack of empirical evidence for globalization are considered 
Table 5 The Top 25 home region-based companies

\begin{tabular}{|c|c|c|c|c|c|c|c|c|c|}
\hline & $\begin{array}{l}500 \\
\text { rank }\end{array}$ & Company & Region & $\begin{array}{l}\text { Revenues } \\
\text { (US\$bn) }\end{array}$ & $\begin{array}{l}F / T \\
\text { sales }\end{array}$ & $\begin{array}{l}\text { Percentage } \\
\text { intra-regional }\end{array}$ & $\begin{array}{c}\text { North America } \\
\text { percentage } \\
\text { of total sales }\end{array}$ & $\begin{array}{c}\text { Europe } \\
\text { percentage } \\
\text { of total sales }\end{array}$ & $\begin{array}{c}\text { Asia-Pacific } \\
\text { percentage } \\
\text { of total sales }\end{array}$ \\
\hline 1 & 1 & Wal-Mart Stores (q) & North America & 219.8 & 16.3 & 94.1 & 94.1 & 4.8 & 0.4 \\
\hline 2 & 3 & General Motors & North America & 177.3 & 25.5 & 81.1 & 81.1 & 14.6 & NA \\
\hline 3 & 5 & Ford Motor & North America & 162.4 & 33.3 & 66.7 & $66.7^{\mathrm{a}}$ & 21.9 & NA \\
\hline 4 & 9 & General Electric & North America & 125.9 & 40.9 & 59.1 & $59.1^{\mathrm{a}}$ & 19.0 & 9.1 \\
\hline 5 & 12 & Mitsubishi & Asia-Pacific & 105.8 & 13.2 & 86.8 & $5.4^{\mathrm{a}}$ & $1.7^{\mathrm{b}}$ & $86.8^{c}$ \\
\hline 6 & 13 & Mitsui & Asia-Pacific & 101.2 & 34.0 & 78.9 & 7.4 & 11.1 & 78.9 \\
\hline 7 & 15 & Total Fina Elf & Europe & 94.3 & NA & 55.6 & 8.4 & 55.6 & NA \\
\hline 8 & 17 & Itochu & Asia-Pacific & 91.2 & 19.1 & 91.2 & 5.5 & 1.7 & 91.2 \\
\hline 9 & 18 & Allianz & Europe & 85.9 & 69.4 & 78.0 & $17.6^{d}$ & 78.0 & $4.4^{\mathrm{e}}$ \\
\hline 10 & 21 & Volkswagen & Europe & 79.3 & 72.3 & 68.2 & 20.1 & 68.2 & 5.3 \\
\hline 11 & 22 & Siemens & Europe & 77.4 & 78.0 & 52.0 & $30.0^{d}$ & 52.0 & 13.0 \\
\hline 12 & 23 & Sumitomo & Asia-Pacific & 77.1 & 12.7 & 87.3 & $4.8^{\mathrm{a}}$ & NA & $87.3^{c}$ \\
\hline 13 & 24 & Philip Morris & North America & 72.9 & 42.1 & 57.9 & $57.9^{\mathrm{a}}$ & 25.8 & NA \\
\hline 14 & 25 & Marubeni (q) & Asia-Pacific & 71.8 & 28.2 & 74.5 & $11.6^{\mathrm{a}}$ & NA & 74.5 \\
\hline 15 & 26 & Verizon Communications & North America & 67.2 & 3.8 & 96.2 & $96.2^{\mathrm{a}}$ & NA & NA \\
\hline 16 & 27 & Deutsche Bank & Europe & 66.8 & 69.0 & 63.1 & 29.3 & 63.1 & 6.5 \\
\hline 17 & 28 & E.ON & Europe & 66.5 & 43.4 & 80.1 & $9.4^{\mathrm{a}}$ & 80.1 & NA \\
\hline 18 & 29 & US Postal Service (q) & North America & 65.8 & 3.0 & 97.0 & $97.0^{\mathrm{a}}$ & NA & NA \\
\hline 19 & 30 & $\operatorname{AXA}(q)$ & Europe & 65.6 & 77.3 & 51.2 & $24.1^{\mathrm{a}}$ & 51.2 & 19.9 \\
\hline 20 & 31 & Credit Suisse & Europe & 64.2 & 73.3 & 60.9 & $34.9^{d}$ & 60.9 & $4.1^{\mathrm{e}}$ \\
\hline 21 & 32 & Hitachi & Asia-Pacific & 63.9 & 31.0 & 80.0 & 11.0 & 7.0 & 80.0 \\
\hline 22 & 34 & $\begin{array}{l}\text { American International } \\
\text { Group }\end{array}$ & North America & 62.4 & NA & 59.0 & $59.0^{f}$ & NA & NA \\
\hline 23 & 35 & Carrefour & Europe & 62.2 & 50.8 & 81.3 & NA & 81.3 & 6.6 \\
\hline 24 & 36 & American Electric Power & North America & 61.3 & 12.3 & 87.7 & $87.7^{\mathrm{a}}$ & $11.8^{\mathrm{b}}$ & NA \\
\hline 25 & 39 & Duke Energy & North America & 59.5 & 13.1 & 96.5 & 96.5 & NA & NA \\
\hline
\end{tabular}

Data are for 2001.

Source: Braintrust Research Group, The Regional Nature of Global Multinational Activity, 2003 (www.braintrustresearch.com).

Notes: ${ }^{a}$ Refers only to the US; ${ }^{b}$ Refers only to the UK; ${ }^{\mathrm{C}}$ Refers only to Japan; ${ }^{\mathrm{d}}$ Refers to Americas; ${ }^{\mathrm{e}}$ Includes Africa; ${ }^{\mathrm{f}}$ Includes only the US and Canada; $\mathrm{NA}=$ not available.

across the field of IB research. Five research areas of particular relevance are selected. The first two areas deal with the foundations of MNE competitive advantage, namely FSAs and location advantages, respectively. The next three areas are related to MNE strategy, structure and performance.

\section{Implications for the relevance of the internalization and internationalization models of international expansion}

The internalization model of foreign expansion (Buckley and Casson, 1976; Rugman, 1981), and especially its eclectic paradigm version, has been the dominant conceptual model in IB research during the past two decades. It suggests that firms will establish foreign affiliates in the case of strong ownership advantages, location advantages, and internalization advantages (Dunning, 1981). The model assumes that MNEs systematically engage in a cost-benefit calculus of all possible entry modes, namely exports, licensing, and FDI (including, more recently, hybrid modes). Here, FDI may be the preferred mode from the outset if governmentimposed and natural market imperfections make exports and licensing impossible or comparatively more expensive, and if the firm has already been operating abroad (Buckley and Casson, 1981).

In contrast, the internationalization model of the Scandinavian school argues that firms will incrementally build foreign operations, starting with low resource commitments in culturally proximate countries, and then expanding these commitments and geographic scope. Here experiential learning is critical, and path dependencies can be observed in the growth of the MNE's experiential knowledge base, especially as regards knowledge of the markets involved (Barkema et al., 1996; Johansson and Vahlne, 1977, 1990). Little integration has occurred 
between the two schools, which have largely flourished on their own without much crossfertilization, and each has a loyal following of researchers. The internalization school focuses at the outset on market imperfections involving business/usage specificity, whereas the internationalization school starts from imperfections arising from location specificity, in the spirit of Ghemawat (2003). The data presented in this paper suggest that the two approaches may actually be closer to each other than usually thought.

The relative lack of market success in host triad regions can be interpreted, at least partly, as a reflection of the limited customer value attributed to home triad region FSAs, whether transferred through exports (FSAs embodied in final products), through licensing (FSAs transferred to foreign licensees), or through FDI (FSAs transferred to foreign affiliates, whether subsidiaries or hybrid units). In such cases the internalization question of optimal entry mode choice becomes redundant. In other words, it is only in locations where the MNE's home region FSAs are valued by customers, as compared with relevant rivals, and for which minimum sales volumes can be expected (at least as far as market-seeking FDI is concerned), that conventional internalization theory is fully relevant. In such case of easy market penetration there is no need for a lengthy learning process, in the sense of an incremental accumulation of host region experience, to compensate for the liability of foreignness. The case of easy market penetration is consistent with Vernon's (1966) product life cycle (whereby all innovations with global market potential originate in one country), but with the choice of entry mode contingent upon transaction cost considerations. Paradoxically, internationalization theory identifies the locations where MNEs have the luxury of such an extensive, transactioncost-driven entry mode selection and where they do not, namely in the case of high location-driven learning requirements. The data suggest that extensive choice options occur mainly in the home triad region, for most companies. Future research should therefore explore in more depth the complementarities, rather than the differences, between the internalization and internationalization perspectives on international expansion.

\section{Implications for research on the diamond of international competitiveness}

Porter (1990) has suggested that international competitiveness at the level of specific industries depends critically on a favorable configuration of home country diamond conditions. Here, four determinants have been viewed as critical: factor conditions (with a focus on created and advanced production factors); demand conditions (with a focus on total demand and sophistication of demand, based on precursor status); related and supporting industries (with a focus on the presence of world-class firms with which cluster type linkages exist); and strategy, structure and rivalry (whereby strong rivalry and benchmarking against the toughest competitors are critical to innovation). Porter's perspective has led to several followup studies, providing extensions and suggestions to augment his path-breaking model (Cartwright, 1993; Dunning, 1996; Moon et al., 1998; Rugman and D'Cruz, 1993; Rugman and Verbeke, 1993; Rugman et al., 1995).

The data in this paper suggest two important extensions of research building upon the diamond concept. First, the diamond may be useful primarily to expand internationally in the home triad region, meaning that 'favorable diamond conditions' in the home country may be insufficient in most cases to permit a truly global expansion. IB research should focus on the reasons for this lack of relevance of the home country diamond in host triad regions.

Second, a limited geographic scope of the national diamond's significance for international competitiveness has asymmetric implications for large economies such as the United States, Japan, and Germany, and small open economies such as Canada, Belgium, and Singapore. For MNEs originating in large countries, it means reassessing the market attractiveness of the so-called small markets in the home triad region. The presence of FSAs instrumental to achieving a high market share in geographically proximate markets, but that are region bound, should refocus these MNEs' efforts from assessing foreign market attractiveness through using macroeconomic data toward developing and using data that better indicate the firm's real market penetration potential, as illustrated by the Tricon case discussed in Ghemawat (2001). As regards MNEs from small open economies, the data suggest that it makes sense to focus on demand in adjacent, large economies that are part of the home region. This is consistent with the double diamond thinking in IB research that focuses on MNEs in these small open economies, much in line with Moon et al. (1998), Rugman and Verbeke (1993), and Rugman et al. (1995). Here it should be 
emphasized that regional integration not only benefits MNEs in the form of creating supply side efficiencies, but also improves market integration on the demand side, for example in terms of positively influencing buyers' confidence, attitudes and purchase intentions vis-à-vis products from foreign countries inside the triad region (Agarwal et al., 2002). Here it would appear that, within one triad region, country of origin effects in purchasing decisions are complemented by 'region of origin' preferences.

\section{Implications for research adopting a resource- based perspective on the integration/national responsiveness framework}

Perhaps the most important implications of the empirical data on triad-based MNE activities are for research adopting a resource-based approach to MNE functioning. The integration/national responsiveness framework, an application to the IB context of the differentiation-integration approach in organization theory (Lawrence and Lorsch, 1967), was developed by Prahalad (1975), and further extended by Doz (1979), Bartlett (1979), and Bartlett and Ghoshal (1989). The integrationnational responsiveness framework was given a TCE and resource-based interpretation by Rugman and Verbeke $(1992,2001)$. The latter authors have argued that benefits of integration, in the form of scale economies, scope economies, and benefits of exploiting national differences, require non-location-bound FSAs. In contrast, benefits of national responsiveness require location-bound FSAs. In this revised model Bartlett and Ghoshal's (1989) transnational solution could be interpreted as a firm that can effectively access and deploy the required dual knowledge bundles (of NLB and LB FSAs) for each activity to be performed, for each product, within each SBU. The data presented in this paper, however, suggest the need for an extension of the framework.

The conventional framework needs to be augmented, as operating in the home triad region may be associated with new needs for the development of region-bound FSAs, imposed by regional integration: see for example the nine cases discussed by Rugman and Verbeke (1991), especially the Volvo Trucks case. Hence regional integration creates both a threat and an opportunity for MNEs as they need to complement the conventional bundles of non-location-bound FSAs and location-bound FSAs with a set of region-bound FSAs. The data in this paper suggest that many of the world's largest and most international MNEs have been quite successful in doing so.

In contrast, few of these firms appear capable of developing and deploying the required set of region-bound FSAs in host regions. The few cases where MNEs have been exceptionally successful in a host region (see Table 4) merit further attention. Here the focus should not be on those firms that acquired a position merely because of a merger (as in the Daimler-Chrysler case), but on those where FSAs have really been built over time, for example by finding ways to access or 'plug in' to pockets of new knowledge (Doz et al., 2001).

Many large MNEs do have a strong geographical dispersion of their sourcing and production, both in resource industries and in manufacturing, but appear incapable (or unwilling) of capitalizing on this position to achieve global sales penetration. The observed asymmetry between sourcing/manufacturing and sales has two critical implications. First, it means that the concept of location-bound vs non-location-bound FSAs needs to be extended. The former concept usually implies that profitable deployment is possible only in the home country. The latter concept assumes global transferability. The data suggest that many MNEs have FSAs that are region bound: that is, they can be deployed across national borders, but only in a limited geographic region. Here, value added through aggregation, in the sense of exploiting similarities across countries (Ghemawat, 2003), can be achieved in the home region but appears difficult across regions. Second, the required MNEs' FSAs in upstream activities to achieve global sourcing (of R\&D outputs, raw materials, intermediate inputs, labor and capital) and production, may be very different from the FSAs required in downstream activities to achieve a global distribution of sales. Here, value added through arbitrage (Ghemawat, 2003) - that is, exploiting differences between countries - appears to be achievable more often across regions.

In this context, Figure 1 shows two hypothetical accumulation patterns over time, of the MNE's FSAs at the upstream end (sourcing/production) and the downstream end (sales). At either end of the value chain these resource bundles consist of non-location-bound FSAs, location (read country)-bound FSAs and region-bound FSAs. The limited market performance achieved in host triad regions suggests that most firms are not capable of accessing and deploying the required knowledge bundles at the downstream end, because these bundles are likely 
to be quite different from the knowledge combinations effective in the home triad region, whereas this does not necessarily hold for more upstream activities. In broader terms, national and home region organizing principles adopted by MNEs, and engrained in their FSAs, appear to limit most MNEs' repertoire of downstream strategies required to be effective in the host region market. This is particularly interesting given that many markets, especially for commodity products, are characterized by 'global' (uniform) prices, driven by 'global' competition. In contrast, it appears much easier to adopt effective sourcing (and manufacturing) strategies associated with a broad geographical coverage. The liability of foreignness faced by the MNE (Hymer, 1976; Zaheer, 1995) thus needs to be unbundled into downstream and upstream components.

The diagonal arrow in Figure 1 shows a hypothetical expansion path over time, whereby the FSAs available for effective global sourcing/production (here in the sense of broad geographical coverage, but not necessarily limited to a triad context, as the optimal geographical configuration of sourcing and production is firm and industry specific) and those for global market penetration grow in very similar ways.

In contrast, the arrow on the left-hand side of the diagonal in Figure 1 reflects a new perspective on the typical large top-500 MNE, which is trapped in its home triad region as far as market penetration is concerned. Here the development of downstream FSAs seriously lags behind the growth in upstream FSAs. It may thus be potentially easy to achieve a global distribution of sourcing/production, whereas a global distribution of sales may be more difficult to accomplish.

To a large extent, much of the recent work on the globalization of particular value chain functions, such as finance, $R \& D$, purchasing and logistics, and

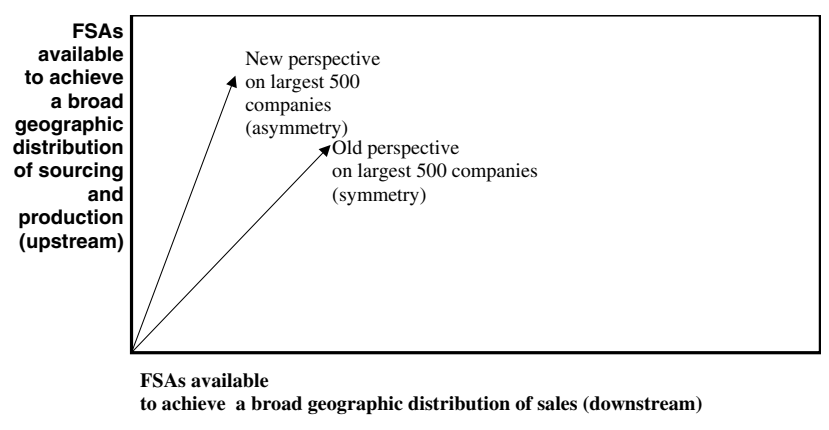

Figure 1 Old and new perspectives on the largest 500 companies. production, has focused solely on the upstream portion of the MNE's FSA bundles. This largely reflects an arbitration issue, with the MNE taking advantage of the incomplete integration of factor markets (Ghemawat, 2003). This may reflect a 'global logic' in the minds of managers, but is distinct from a strong global market performance.

\section{Implications for research on MNE structure}

A large body of work has been written on the need for a fit between strategy and structure in MNEs, as a precondition for survival, profitability and growth, much in line with mainstream work in strategy and industrial organization on domestic firms. In this particular case the strategic importance of each triad region, combined with the different market characteristics faced by MNEs in each of these regions, would suggest the introduction of geographic components in the MNEs' structure.

The data in this paper, suggesting a strong discrepancy between intra-regional and inter-regional sales, may have important implications for MNE structure. In addition, the differentiation between downstream and upstream activities, building upon different sets of FSAs, should be reflected in the MNE's organizational structure, systems and perhaps even culture.

Several papers have been written on regional components in MNE organizational structure, such as regional headquarters (Daniels, 1987; D'Cruz, 1986; Dunning and Norman, 1987; Grosse, 1981; Heenan, 1979; Lasserre, 1996; Morrison et al., 1991). Yeung et al.'s (2001) analysis of such regional headquarters in Singapore argues that their roles will depend on a number of parameters, which include geographical distance, familiarity with the host region, commitment to the host region, and regional integration, thus implicitly suggesting the importance of using the regional headquarters to complement in an idiosyncratic way each MNE's existing FSA bundles.

More research is needed that links the required knowledge bundles for each critical value-added activity in host triad regions with specific structural elements, which may also include elements of organizational physiology and psychology (Yeung et al., 2001). Here it should be recognized that such regional elements may increase the difficulty of managing multidivisional (M-form) companies, as performance evaluation should be differentiated for units operating in the various regions, even within similar businesses, given the enormous differences 
in environmental circumstances faced by the affiliates in each region. In other words, even at a single point in time, MNEs may adopt both participative decentralization and administrative centralization simultaneously.

These two approaches have traditionally been viewed as inefficient corruptions of the M-form (Freeland, 1996; Williamson, 1975), but may in reality constitute a precondition for the effective governance of MNEs with regional strategies. Here participative decentralization reflects the involvement of regional divisions in corporate strategic planning, and this may be critical for successfully conducting downstream activities in host regions, given both the relative lack of appropriate information at the corporate headquarters' level on host regions, and the need to preserve subsidiary commitment and initiative in those host regions. In contrast, administrative centralization may be more appropriate for the management of upstream activities across regions, given the relative availability of information at corporate headquarters on these activities and the possibility of reducing both production and coordination costs through optimally exploiting imperfections in national and regional factor markets.

\section{Implications for research on the performance effects of geographical diversification}

Much of the literature on geographical diversification has attempted to evaluate the impact of diversification on profit performance (Buckley et al., 1977, 1984; Geringer et al., 1989; Hitt et al., 1997; Morck and Yeung, 1991; Rugman, 1976). Usually some proxy is adopted for the share of foreign sales in total sales (or in some cases a more upstream end related measure, such as the number of subsidiaries abroad) to assess the degree of geographical diversification. Recent research has established the importance of the home country environment - that is, the locus of origin of geographic diversification efforts - for the scope and financial performance effects of geographic diversification (Wan and Hoskisson, 2003).

In this paper, however, we emphasize the importance of the locus of destination. The relative sales in host triad regions, vis-à-vis the home triad region, are themselves a critical performance parameter. Perhaps the mixed results in past research on the profit impact of geographical diversification, may be partly explained by (1) a lack of investigation of the locus of destination of the diversification efforts (intra-regional $v s$ inter-regional), and (2) the fact that market share success in non-home triad markets may be at the expense of profit performance. Thus future research on the impacts of geographic diversification should study explicitly the regional patterns and scope of MNE sales growth. In addition, it could include relative sales in host region markets as a performance parameter (dependent variable), rather than as a mere independent variable affecting financial profitability. Recent work by Vermeulen and Barkema (2002) correctly points out that some benefits of international expansion (such as tax benefits, common purchasing, and improved access to inexpensive labor) are easier to realize than other benefits, which require learning. Although these authors do not view host region market penetration performance relative to home region performance as a proxy for international success, their work does suggest that a broader geographic scope of the expansion process negatively moderates the impact of a firm's foreign subsidiaries on its profitability. More specifically, they demonstrate that a broader geographic scope strains the MNE's absorptive capacity (Cohen and Levinthal, 1990), particularly in the short run, leading to time compression diseconomies. They also show that foreign expansion is easier to absorb for MNEs if it occurs in 'related' countries, following the classification of countries into clusters developed by Ronen and Shenkar (1985).

Another recent paper by Ruigrok and Warner with a focus on upstream FSAs confirms this perspective. Ruigrok and Wagner (2003) suggest that US firms are usually characterized by an inverted J-curve, in terms of internationalization impact on performance (measured by return on assets). Internationalization is associated with performance improvements, until a threshold is reached, when performance starts to decline. The reason is that US firms usually expand in a first stage to culturally proximate countries such as Canada, the United Kingdom and Australia. In contrast, German firms face a U-curve in terms of performance effects of internationalization. A low psychic distance is found in only two small economies, namely Austria and Switzerland, which implies that German firms are required to target a much wider and more varied market (the EU) from the outset, thereby incurring higher learning costs. Ruigrok and Wagner's (2003) perspective on upstream internationalization suggests that, even there, the linkages between country of origin and country of destination are critical in determining 
the optimal route of internationalization and organizational learning.

This is an important observation, as influential work in IB has argued that the operational flexibility of MNEs, resulting from their internationally dispersed network of affiliates, confers arbitraging advantages, information-related network externalities, etc. (Kogut, 1983; Kogut and Kulatilaka, 1994). However, the analysis above suggests that the locus of destination determines the extent to which such benefits can be earned. More specifically, a lower (cultural, administrative, geographic and economic) distance, although reducing the hypothetical, maximum arbitraging and network externality benefits, will facilitate earning such benefits in practice.

Future research should investigate whether the prior existence of a strong internal network in the home region (and the related proven ability to learn and to manage risks) is critical for subsequent positive performance effects of inter-regional expansion. The creation of a strong competitive position in the home region may reflect one step in an evolutionary strategy of resource recombinations, which follows a clear sequential pattern and creates platforms for future investments (Kogut and Zander, 1993). However, it is unclear whether such platforms are themselves truly non-locationbound, or can only be applied in a limited geographic space.

\section{Conclusions}

Most large MNEs have an average of $80 \%$ of total sales in their home triad region. Only nine firms among the largest 500 companies are unambiguously global. What are the normative implications of this observation? It could be argued that these few examples of global corporate success should be viewed as best practices and benchmarks, to be carefully studied, and emulated by other large MNEs, most of which are characterized by a much more narrow and shallow penetration of host region markets. However, the observed weak market position in host regions, as compared with the home triad market, may also be interpreted as the outcome of a rational preference for regionally based activities, resulting from a careful cost-benefit calculation. Here, strategic interactions among large players, taking the form of 'inter-regional chess', may influence international sales patterns and the selection of target markets.

More generally, it could be argued, from a coevolutionary perspective, that regional strategies of
MNEs are embedded in - and co-evolve with - the broader competitive, organizational and institutional contexts at the regional level, in the spirit of Koza and Lewin (1998). In this situation, MNE regional strategy choices evolve interdependently with changes in prevailing industry practices, legitimate organizational forms, government regulations, etc. It should be recognized that regions themselves may change over time (as with the inclusion of all the Americas in NAFTA and further EU expansion), and therefore provide new opportunities for MNE growth. The triad perspective developed in this paper should therefore be viewed as a starting point for future empirical analyses, recognizing that regionalization is openended over time.

When globalization does occur, it is restricted to the upstream end of the value chain. Some of the world's largest MNEs master the art of connecting globally dispersed inputs. These can be in the form of financial capital, human capital, R\&D knowledge, components, etc., and can be integrated to better serve home region clients. Hence it appears possible to be global at the upstream end of the value chain, and much can undoubtedly be learned from observing and imitating the routines of global leaders in this portion of the value chain.

Does this imply that large MNEs should be complacent as far as the downstream end is concerned and focus solely on their home region of the triad? Probably not, but senior MNE management should understand that widespread geographic diversification may well have managerial pitfalls similar to the conventional drawbacks of product diversification. A clear focus is required in terms of scope of geographic expansion, and the economic evaluation of international growth plans must take into account the costs of inter-regional 'distance' and the liability of inter-regional foreignness.

Finally, this paper has uncovered two fundamental paradoxes of IB that so far have eluded most, if not all, scholars in the field. First, at the downstream end, national responsiveness and localized adaptation are almost universally advocated as a panacea for penetrating international markets, but in reality most MNEs attempt to add value primarily by capitalizing on similarities across markets. This is an aggregation strategy often met with success in the home region. Second, at the upstream end (including FDI-driven foreign manufacturing), opportunities for scale and scope are usually considered abundant. Yet, in reality, MNEs add value primarily through arbitrage - that is, 
exploiting differences across nations and regions. Successful integration thus reflects locational specificities, and entails a process of internalization arbitrage: it refers essentially to the combination of the MNE's upstream FSAs, deployed in host countries, with these countries' location advantages.

We live in a world of semi-globalization, where IB research needs to rethink fundamentally the substance of aggregation and arbitrage opportunities. A renewed focus on MNE strategies, distinguishing between home and host triad regions, and between upstream and downstream activities, may be a good starting point for such an endeavor.

\section{References}

Agarwal, J., Malhotra, N. and Wu, T. (2002) 'Does NAFTA influence Mexico's product image? A theoretical framework and an empirical investigation in two countries', Management International Review 42(4): 441-471.

Barkema, H., Bell, J. and Pennings, J. (1996) 'Foreign entry, cultural barriers and learning', Strategic Management Journal 17(2): 151-166.

Bartlett, C. (1979) 'Multinational structural evolution: the changing decision environment in international divisions', Doctoral dissertation Harvard Graduate School of Business Administration.

Bartlett, C. and Ghoshal, S. (1989) Managing Across Borders: The Transnational Solution, Harvard Business School Press: Boston, MA.

Buckley, P.J. and Casson, M.C. (1976) The Future of the Multinational Enterprise, Macmillan: London.

Buckley, P.J. and Casson, M.C. (1981) 'The optimal timing of a foreign direct investment', Economic Journal 91(361): 75-87.

Buckley, P.J., Dunning, J.H. and Pearce, R.B. (1977) 'The influence of firm size, sector, nationality, and degree of multinationality in the growth and profitability of the world's largest firms', Weltwirtschaftliches Archiv 114: 243-257.

Buckley, P.J., Dunning, J.H. and Pearce, R.B. (1984) 'An analysis of the growth and profitability of the world's largest firms 1972 to 1977 ', Kyklos 37(1): 3-27.

Cartwright, W.R. (1993) 'Multiple linked diamonds and the international competitiveness of export-dependent industries: the New Zealand experience', Management International Review 33(2): 55-70.

Cohen, W. and Levinthal, D. (1990) 'Absorptive capacity: a new perspective on learning and innovation', Administrative Science Quarterly 35: 128-152.

Daniels, J. (1987) 'Bridging national and global marketing strategies through regional operations', International Marketing Review 4(3): 29-44.

D'Cruz, J. (1986) 'Strategic Management of Subsidiaries', in $\mathrm{H}$. Etemad and L.S. Dulude (eds.) Managing the Multinational Subsidiary, Croom Helm: London, pp. 75-80.

Doz, Y. (1979) Government Control and Multinational Strategic Management: Power Systems and Telecommunications Equipment, Praeger: New York.

Doz, Y., Santos, J. and Williamson, P. (2001) From Global to Metanational, Harvard Business School Press: Boston, MA.

Dunning, J.H. (1981) International Production and the Multinational Enterprise, George Allen \& Unwin: London.

Dunning, J.H. (1996) 'The geographic sources of competitiveness of firms: some results of a new survey', Transnational Corporations 5(3): 1-30.

Dunning, J.H. (2001) 'The Key Literature on IB Activities: 1960 $2000^{\prime}$, in A.M. Rugman and T.L. Brewer (eds.) The Oxford

\section{Acknowledgements}

An earlier version of this paper was presented at the Duke University JIBS and CIBER Conference on 'Emerging Frontiers in International Business Research', 6-9 March 2003. We are pleased to acknowledge the help of Arie Lewin in stimulating this article. Helpful comments on earlier drafts have been provided by Vern Bachor, Paul Beamish, Peter Buckley, Yves Doz, John Dunning, Michael Enright, Stephane Girod, Robert Grosse, Mike Kotabe, Mitchell Koza, Klaus Meyer, John Mezias, Karl Moore, Mona Sellers, Lorn Sheehan, and two anonymous JIBS referees. We also acknowledge the excellent research assistance of Cecilia Brain.

Handbook of International Business, Oxford University Press: Oxford, pp. 36-68.

Dunning, J. and Norman, G. (1987) 'The location choice of offices of international companies', Environmental Planning $A$ 19: 613-631.

Freeland, R.F. (1996) 'The myth of the M-Form? Governance, consent, and organizational change', American Journal of Sociology 102(2): 483-526.

Geringer, J.M., Beamish, P. and daCosta, R.C. (1989) 'Diversification strategy and internationalization: implications for MNE performance', Strategic Management Journal 10(2): 109-119.

Ghemawat, P. (2001) 'Distance still matters: the hard reality of global expansion', Harvard Business Review 79(8): 137-147.

Ghemawat, P. (2003Q5) 'Semiglobalization and international business strategy', Journal of International Business Studies 34(2): 138-152.

Govindarajan, V. and Gupta, A. (2001) The Quest for Global Dominance, Jossey-Bass/Wiley: San Francisco.

Grosse, R. (1981) 'Regional offices of MNCs', Management International Review 21: 48-55.

Hamel, G. and Prahalad, C.K. (1985) 'Do you really have a global strategy?', Harvard Business Review 63(4): 139-148.

Heenan, D.A. (1979) 'The regional headquarters division: a comparative analysis', Academy of Management Journal 22(2): 410-415.

Hitt, M.A., Hoskisson, R.E. and Kim, H. (1997) 'International diversification: effects on innovation and firm performance in product-diversified firms', Academy of Management Journal 40: 767-798.

Hymer, S. (1976) The International Operations of National Firms, MIT Press: Cambridge, MA.

Jeannet, J.P. (2000) Managing with a Global Mindset, Financial Times/Prentice Hall, Pearson: London.

Johansson, J. and Vahlne, J.E. (1977) 'The internationalization process of the firm: a model of knowledge development and increasing foreign market commitments', Journal of International Business Studies 8(1): 23-32.

Johansson, J. and Vahlne, J.E. (1990) 'The mechanism of internationalization', International Marketing Review 7(4): $1-24$.

Kogut, B. (1983) 'Foreign Direct Investment as a Sequential Process', in: C.P. Kindleberger and D.B. Audretsch (eds.) The Multinational Corporation in the 1980s, MIT Press: Cambridge, MA, pp. 38-56.

Kogut, B. and Kulatilaka, N. (1994) 'Operating flexibility, global manufacturing, and the option value of a multinational network', Management Science 40(1): 123-139.

Kogut, B. and Zander, U. (1993) 'Knowledge of the firm and the evolutionary theory of the multinational enterprise', Journal of International Business Studies 24(4): 625-645. 
Koza, M.P. and Lewin, A.Y. (1998) 'The co-evolution of strategic alliances', Organization Science 9(3): 255-264.

Lasserre, P. (1996) 'Regional headquarters: the spearhead for Asia Pacific markets', Long Range Planning 29: 30-37.

Lawrence, P. and Lorsch, J. (1967) Organization and Environment, Harvard Business School, Division of Research: Boston, MA.

Levitt, T. (1983) 'The globalization of markets', Harvard Business Review, May-June(3): 92-102.

Moon, C., Rugman, A.M. and Verbeke, A. (1998) 'A generalized double diamond approach to the global competitiveness of Korea and Singapore', International Business Review 7(2): 135-150.

Morck, R. and Yeung, B. (1991) 'Why investors value multinationality', Journal of Business 64(2): 165-187.

Morrison, A.J., Ricks, D.A. and Roth, K. (1991) 'Globalization versus regionalization: which way for the multinational?', Organizational Dynamics 19(3): 17-29.

Ohmae, K. (1985) Triad Power: The Coming Shape of Global Competition, The Free Press: New York.

Perlmutter, H. (1969) 'The tortuous evolution of the multinational enterprise', The Columbia Journal of World Business 4(1): 9-18.

Porter, M.E. (1990) The Competitive Advantage of Nations, The Free Press: New York.

Prahalad, C.K. (1975) 'The strategic process in a multinational corporation', Doctoral dissertation Harvard Graduate School of Business Administration.

Ronen, S. and Shenkar, O. (1985) 'Clustering countries on attitudinal dimensions: a review and syntheses', Academy of Management Review 10: 435-454.

Rugman, A.M. (1976Q10) 'Risk reduction by international diversification', Journal of International Business Studies 7(2): 80-85.

Rugman, A.M. (1981) Inside the MultinationalsThe Economics of Internal Markets, Columbia University Press: New York.

Rugman, A.M. (2000) The End of Globalization, Random House: London/Amacom-McGraw-Hill: New York.

Rugman, A.M. and Brain, C. (2003) 'Multinational enterprises are regional, not global', Multinational Business Review 11(1): 3-12.

Rugman, A.M. and D'Cruz, J.R. (1993) 'The 'double diamond' model of international competitiveness: the Canadian experience', Management International Review 33(Special Issue 1993/2): 17-40.

Rugman, A.M. and Girod, S. (2003) 'Retail multinationals and globalization: the evidence is regional', European Management Review 21(1): 24-37.

Rugman, A.M., Van den Broeck, J. and Verbeke, A.J. (eds.) (1995) Global Strategic Management: Beyond the Diamond, JAI Press: Greenwich, CN.

Rugman, A.M. and Verbeke, A. (1991) 'Environmental Change and Global Competitive Strategy in Europe', in A. Rugman and A. Verbeke (eds.) Global Competition and the European Community, JAI Press: Greenwich, CN, pp. 3-28.

Rugman, A.M. and Verbeke, A. (1992) 'A note on the transnational solution and the transaction cost theory of multinational strategic management', Journal of International Business Studies 23(4): 761-771.

Rugman, A.M. and Verbeke, A. (1993) 'Foreign subsidiaries and multinational strategic management: an extension of Porter's single diamond framework', Management International Review 33(2): 71-84.

Rugman, A.M. and Verbeke, A. (2001) 'Subsidiary-specific advantages in multinational enterprises', Strategic Management Journal 22(3): 237-250.

Rugman, A.M. and Verbeke, A. (2003) 'The World Trade Organization, Multinational Enterprises, and the Civil Society', in M. Fratianni, P. Savona and J. Kirton (eds.) Sustaining Global Growth and Development, Ashgate: Aldershot, pp. 81-97.
Ruigrok, W. and Wagner, H. (2003) 'Internationalization and performance: an organizational learning perspective', Management International Review 43(1): 63-83.

United Nations (2002) World Investment Report 2002, UN Conference on Trade and Development: New York and Geneva.

Van den Bulcke, D. (1995) 'The Strategic Management of Multinationals in a Triad-based World economy', in A.M. Rugman, J. Van den Broeck and A. Verbeke (eds.) Global Strategic Management: Beyond the Diamond, JAI Press: Greenwich, CN, pp. $25-63$.

Vermeulen, F. and Barkema, H. (2002) 'Pace, rhythm, and scope: process dependence in building a profitable multinational corporation', Strategic Management Journal 23: 637-653.

Vernon, R. (1966) 'International investment and international trade in the product cycle', Quarterly Journal of Economics 80: 190-207.

Wan, W.P. and Hoskisson, R.E. (2003) 'Home country environments, corporate diversification strategies and firm performance', Academy of Management Journal 46(1): 27-45.

Williamson, O.E. (1975) Markets and Hierarchies: Analysis and Antitrust Implications., Free Press: New York.

Yeung, H., Wai-chung, P., Martin, J. and Martin, P. (2001) 'Towards a regional strategy: the role of regional headquarters of foreign firms in Singapore', Urban Studies 38(1): 157-183.

Yip, G. (2002) Total Global Strategy II, Prentice Hall: Upper Saddle River, NJ.

Zaheer, S. (1995) 'Overcoming the liability of foreignness', Academy of Management Journal 38(2): 341-363.

\section{About the authors}

Alan M Rugman is L Leslie Waters Chair of International Business and a professor at the Kelley School of Business, Indiana University, Bloomington, USA. He is also Director of the IU CIBER. He is also an Associate Fellow of Templeton College, University of Oxford. Previously, he was a professor at the University of Toronto in Canada. He has published numerous books and articles dealing with the strategic management of multinational enterprises and trade and investment policy. His recent books include: the Oxford Handbook of International Business (2001), Multinationals as Flagship Firms (2000), and Environmental Regulations and Corporate Strategy (1999), all published by Oxford University Press.

Alain Verbeke holds the McCaig Chair in Management at the Haskayne School of Business, University of Calgary (Canada), and is an Associate Fellow of Templeton College, University of Oxford (UK). He was previously the Director of the MBA programme, Solvay Business School, Free University of Brussels (VUB) (Belgium), and has extensive practical experience in multinational strategic planning and complex project evaluation. This is his seventh article in JIBS. 